\title{
PERBAIKAN MANUFAKTUR PENDINGIN UDARA MESIN PEMBANGKIT JGS 420 UNTUK MENCEGAH KONTAMINASI
}

\section{MANUFACTURING IMPROVEMENT OF CHARGE AIR COOLERJGS 420 GENERATOR TO AVOID CONTAMINATIONS}

\author{
Amin Suhadi ${ }^{\mathrm{a}}$, Tomi Abdillah ${ }^{\mathrm{b}}$, \\ ${ }^{a}$ Peneliti Pada Balai Besar Teknologi Kekuatan Struktur, BPPT \\ Kawasan PUSPIPTEK, Serpong, Tangerang 15314 \\ Tel. (021)-7560539; Fax. (021)-7560538,E-mail :aminsuhadi@gmail.com \\ ${ }^{\mathrm{b}}$ ProgramPascaSarjanaMagister Teknik, Universitas Pancasila,Jl.Borobudur No.7 \\ Telp/Fax:021-31926047, E-mail: t.abdillah@yahoo.co.id
}

\begin{abstract}
Abstrak
Perusahaan pembangkit listrik PT.XYZ mengoperasikan mesin pembangkit type JGS 420 dengan bahan bakar gas.Dalam proses pembuatannya digunakan bahan tembaga, namun berdampak negativ, yaitu menghasilkan kontaminasi terhadap oli yang digunakan. Karena itu perlu dilakukan perbaikan proses manufaktur untuk mencegah kontaminasi tersebut. Karena itu penelitian ini bertujuan untuk memperbaiki manufaktur pendingin udara tersebut agar terhindar dari proses kontaminasi dengan memanfaatkan material tahan korosi yaitu baja tahan karat 304. Metode penelitian dilakukan dengan observasi dilapangan, pengujian olisebelum dilakukan pergantian material dan perbandingan setelah pergantian, simulasi Ansys dan evaluasi reliabilitas mesin. Hasil penelitian menunjukkan bahwa pemanfaatan material baja tahan karat sebagai sirip pendingin udara sebagai pengganti material tembaga mampu mengurangi kontaminasi tembaga sehinggapemakaian pelumas lebih efisien.
\end{abstract}

Kata kunci : manufaktur, pendingin, pembangkit

\begin{abstract}
Power energy company PT.XYZ is operating power generator JGS 420type with gas fuel. Copper was used to build charge air cooler, but negative effect has appeared during operation, it has contaminated oil that was used. Therefore, the development of manufacturing is needed to avoid this contamination. The aim of this research is to improvemanufacturing process to protect agains contamination byimplementing 304 stainless steel for air cooler fin. Research method was conducted by insitu observations, lubrication analysis both before replacing $\mathrm{Cu}$ with stainless steel and after replacing, simulations using Ansys and machine reliability monitoring. Experimental result indicates that replacing $\mathrm{Cu}$ by stainless steel on manufacturing of fin air cooler could reduce contaminants content significantly, therefore efficiency of oil lubricants was increased.
\end{abstract}

Keywords: manufacture, cooler,generator

Diterima (received) : 20 Februari 2017, Direvisi (reviewed) : 13 Maret 2017, Disetujui (accepted) : 05 April 2017

\section{PENDAHULUAN}

Keberlangsungan operasional mesin dalam suatu sistem produksi memiliki peran yang sangat penting dalam rangka menunjang pemenuhan target perusahaan. Periode waktu mesin tidak operasi diluar jadwal pemeliharaan menjadi masalah serius 
yang dapat mengganggu sistem produksi ${ }^{1)}$. Perusahaan pembangkit listrik mesin Diesel gas berbahan natural gas yang memproduksi daya Isitrik menghadapi berbagai macam tantangan dalam pengoperasian mesin diantaranya adalah sistem pelumasan yang tidak efisien, terjadinya kebocoran pelumas, kontaminasi pelumas dan penguapan pelumas membuat konsumsi pemakaian pelumas meningkat ${ }^{2)}$.

Data spesifikasi mesin gas Diesel JGS 420 :

\begin{tabular}{|c|c|}
\hline $\begin{array}{ll}\text { Merek } & : \\
\text { tipe } & : \\
\text { jumlah silinder } \\
\text { bahan bakar } \\
\text { putaran mesin } \\
\text { daya dihasilkan } \\
\text { volume pelumas } \\
\text { waktu pergantian } \\
\text { penambahan peluma } \\
\text { konsumsi pelumas } \\
\text { jenis pelumas }\end{array}$ & $\begin{array}{l}\text { : GE Jenbacher } \\
: \text { JGS } 420 \\
: 20 \text { silinder } \\
: \text { gas alam } \\
: 1500 \mathrm{rpm} \\
: 1,14 \mathrm{MW} \\
: 457 \text { liter } \\
: 2000 \text { jam }\end{array}$ \\
\hline
\end{tabular}

Mesin gas Diesel kategori mesin putaran tinggi (high speed) memiliki life time pelumas rata-rata dapat bertahan hingga 2000 jam. Secara aktual umur pelumas dipengaruhi oleh kualitas pelumas, performa mesin dan pola operasional mesin sehingga pergantian pelumas diluar jadwal tidak dapat terjadi. Parameter untuk menentukan pelumas yang dipakai mesin masih layak untuk digunakan ataukah tidak melalui metoda yang disebutused oil analisis (UOA) di laboratorium. Uji used oil analisis (UOA) dilaboratorium sangat dibutuhkan untuk menunjang perawatan berkala (predictive maintenance) sehingga dapat dilakukan tindakan pencegahan (preventif) untuk mengantisipasi periode waktu mesin tidak operasi (down time) diluar jadwal pemeliharaan (maintenance). Disamping itu dapat memantau kondisi operasi mesin dan menjaga kinerja mesin agar tetap dapat berjalan dengan optimal.

Pendingin udara (charge air cooler) sangat dibutuhkan oleh mesin gas Diesel untuk menghasilkan daya yang optimal. Udara yang dikompresikan oleh turbine turbo charger dengan tekanan tinggi mengakibatkan temperatur udara meningkat sehingga dibutuhkan pendingin udara untuk mendinginkan udara sebelum udara masuk ke dalam ruang bakar. Pendinginan sendiri merupakan system yang diperlukan oleh mesin diesel untuk menjaga komponenkomponen mesin mengalami transfer panas yang tinggi. Terutama komponen yang bersinggungan langsung dengan gas hasil pembakaran memerlukan pendingin, media pendinginannya dapat berupa oli maupun air $^{3)}$.

Piston, main bearing, crank pin bearing, small pin bearing, bushing rocker arm, injector dan bearing merupakan komponenkomponen dari mesin diesel yang didinginkan oleh media oli. Sedangkan bagian luar dari silinder liner, jaket silinder head, jaket turbocharger dan intercooler merupakan komponen-komponen dari mesin diesel yang didinginkan oleh media air. Material yang digunakan untuk elemen pendingin adalah material dengan daya hantar yang tinggi. Umumnya menggunakan bahan tembaga, ada juga yang menggunakan bahan alumunium dengan pertimbangan harga yang jauh lebih murah. Akan tetapi bahan tembaga akan menghasilkan efesiensi pendinginan yang lebih besar dari pada elemen yang menggunakan bahan dari alumunium. Konstruksi dar isistim pendingin tersebut terdapat sirip-sirip (fin) tipis yang dipasang sepanjang saluran. Bentuk dari sirip tersebut dipilih karena berfungsi untuk memperluas permukaan dan memperbanyak kontak dengan media sehingga perpindahan panas lebih banyak terjadi. Selain itu sirip-sirip ini juga digunakan sebagai perekat di antara saluran-saluran ${ }^{4)}$.

Beberapa hal yang mempengaruhi kinerja alat pendingin udara (charge air cooler) antara lain :

A. Temperatur udara masuk yang telah bercampur dengan bahan bakar gas.

B. Kelembaban (humidity) yang menyebabkan proses kondensasi

C. Kotoran debu

D. Laju aliran perpindahan kalor.

\section{BAHAN DAN METODE}

Metode yang digunakan pada penelitian ini adalah metode teoritis, analisis dan pengembangan. Kajian secara teoritis penjelasan utama fenomena atau data dikembangkan, diusulkan dan diuraikan. Untuk mendapatkan parameter-parameter utama dalam charge air cooler dengan berbagai sumber literatur baik berupa buku pedoman maupun jurnal. Pendekatan secara analisis dilakukan dengan pengamatan (visualisasi) kinerja operasional charge air cooler dan pengambilan data operasional harian yang dikoleksi dan diteliti dijadikan petunjuk penelitian.Material yang dipilih adalah baja tahan karat 304 (Stainless steel) dengan pertimbangan unjuk kerja 
Perbaikan manufaktur Pendingin Udara mesin Pembangkit JGS 420 untuk Mencegah Kontaminasi (Amin Suhadi, Tomi Abdillah)

perpindahan panasnya, serta kemudahan fabrikasi dan harga yang tidak mahal.

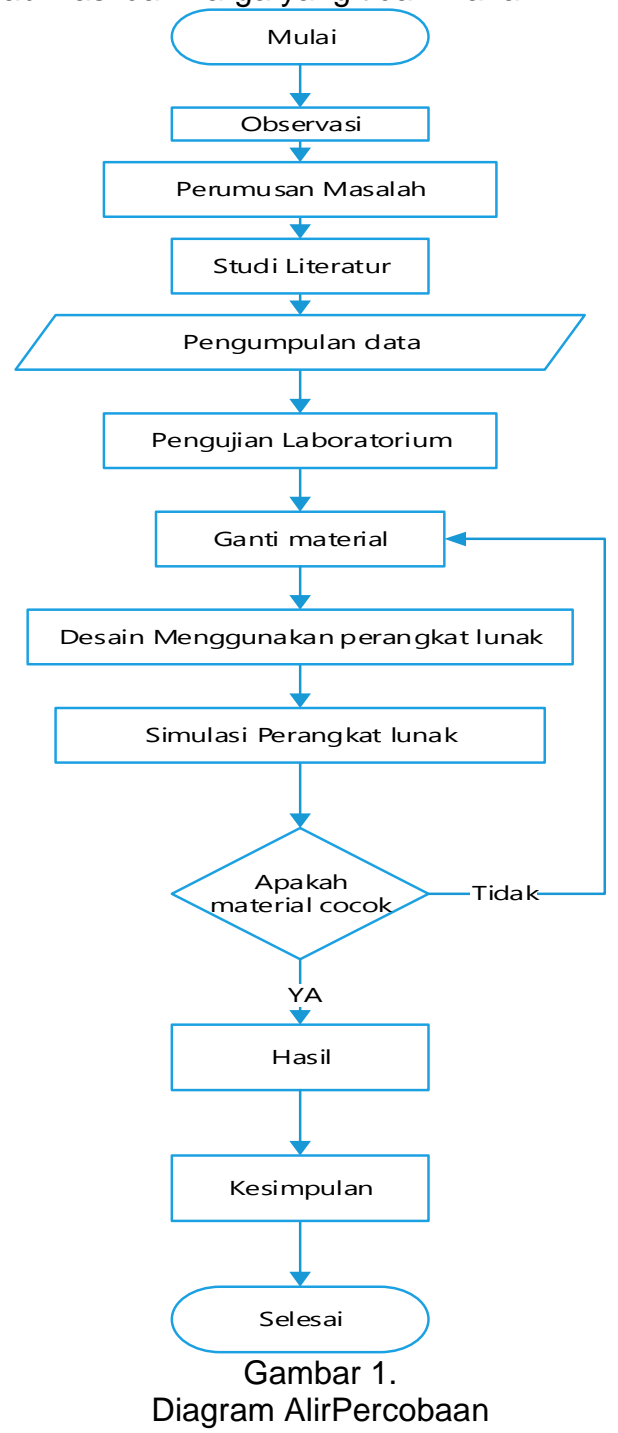

\section{HASIL DAN PEMBAHASAN}

Dari rangkaian tahapan penelitian seperti yang diutarakan dalam gambar 1 dan setelah dilakukan pengujian, simulasi dan analisa, serta pengamatan, maka didapat hasil-hasil yang dapat di lihat pada tabel 1 dan 2 serta pada gambar 2 sampai gambar 12.

Berdasarkan latar belakang masalah penelitian yang telah diutarakan pada pendahuluan maka dari hasil pengujian diharapkan dapat diketahui perbedaan dan perbandingan material pendingin udara (charge air cooler) dari bahan tembaga dengan material pendingin udara (charge air cooler) dari material baja tahan karat (Stainless steel) serta pengaruhnya terhadap tingkat kontaminasi.

\section{Hasil Pengujian Used Oil Analysis (UOA)}

Hasil Pengujian Used Oil Analysis (UOA) Sebelum Dilakukan Pergantian Material Tembaga (Cu) dapat dilihat pada Tabel 1.TBN adalah jumlah total kandungan larutan basa (Total Base Number) sedangkan TAN adalah jumlah total kandungan asam (Total Acid Number). Dari Tabel 1 dapat dilihat bahwa pada pemakaian bahan tembaga sebagai pendingin menghasilkan kontaminasi tembaga yang cukup besar.

Tabel 1.

Data PengujianUsed Oil Analysis

\begin{tabular}{c|c|c|c|c|c|c|c}
\hline $\begin{array}{c}\text { Tanggal } \\
\text { Sampel }\end{array}$ & $\begin{array}{c}\text { Masa } \\
\text { Pakai Oli }\end{array}$ & $\begin{array}{c}\text { Viscositas } \\
\mathbf{1 0 0} \mathbf{C} \\
(\mathbf{c S t})\end{array}$ & $\begin{array}{c}\text { TBN } \\
(\mathbf{m g} \cdot \mathbf{K O H})\end{array}$ & $\begin{array}{c}\text { TAN } \\
(\mathbf{m g} \cdot \mathbf{K O H} / \mathbf{g})\end{array}$ & $\begin{array}{c}\text { Air } \\
(\mathbf{p p m})\end{array}$ & $\begin{array}{c}\text { Besi } \\
(\mathbf{p p m})\end{array}$ & $\begin{array}{c}\text { Tembaga } \\
(\mathbf{p p m})\end{array}$ \\
\hline Oli Baru & 0 & 13.0 & 4.5 & 4.5 & 0 & 0 & 0 \\
25-Jan-08 & 1313 & 14.8 & 3.10 & 3.01 & 0 & 13 & 7 \\
03-Mar-08 & 2187 & 14.1 & 3.92 & 1.77 & 0 & 5 & 4 \\
23-Mar-08 & 2659 & 15.70 & 3.13 & 0.73 & 0 & 4 & 13 \\
11-Oct-08 & 1390 & 14.00 & 3.05 & 1.67 & 0 & 15 & 204 \\
10-Dec-08 & 636 & 14.00 & 6.22 & 4.77 & 0 & 8 & 85 \\
\hline
\end{tabular}




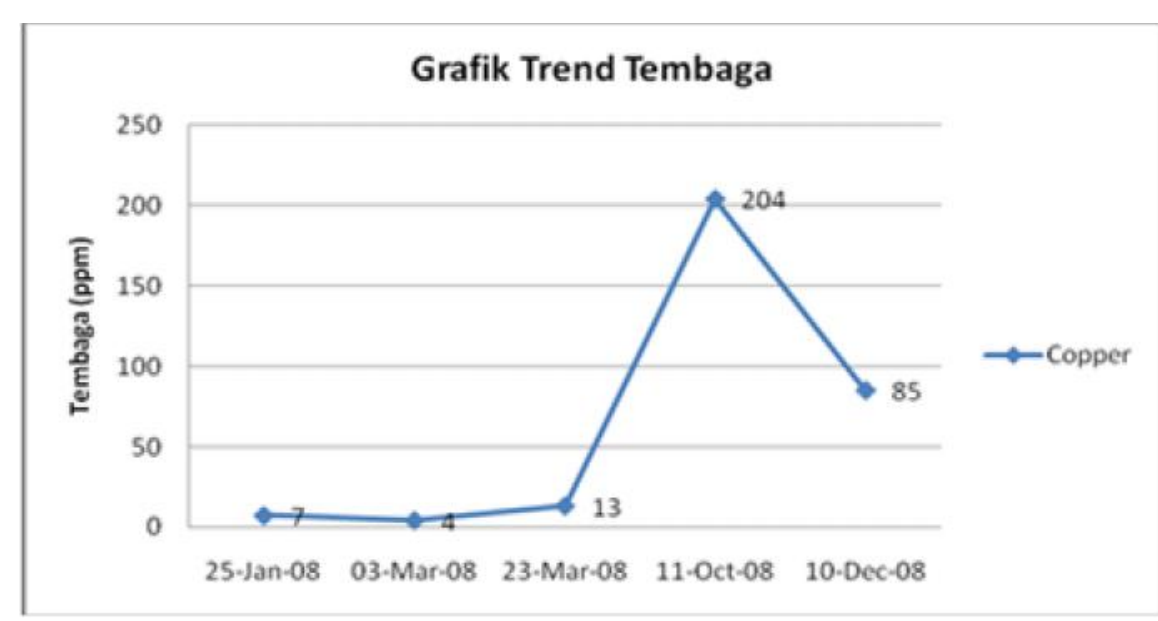

Gambar 2.

Grafik Peningkatan Kontaminasi Tembaga (Cu)

Grafik pada Gambar 2 menunjukkan bahwa pelumas yang digunakan mengalami kontaminasi partikel padat tembaga $(\mathrm{Cu})$. Nilai partikel tembaga dari waktu ke waktu selama periode pengujian used oil analysis (UOA) mengalami peningkatan melampaui dari limit maximal yang diijinkan. Awalnya kontaminasi partikel tembaga sebesar 13 (ppm) lalu meningkat menjadi 204 (ppm) lalu menurun menjadi 85 (ppm). Partikel logam yang terkontaminasi ke dalam pelumas akan mempengaruhi kinerja mesin karena bisa terjadi pergesekan antara dua benda metal antar permukaan logam (metal to metalcontact) yang bergerak ${ }^{1,5,6)}$. Keausan abrasif dapat terjadi bila suatu partikel keras dari material tertentu meluncur pada permukaan material lain yang lebih lunak sehingga terjadi penetrasi atau pemotongan material yang lebih lunak.

Tabel 2.

Hasil Pengujian Used Oil Analysis (UOA) Setelah Dilakukan Pergantian Material Baja Tahan Karat (Stainless Steel)

\begin{tabular}{|c|c|c|c|c|c|c|c|}
\hline $\begin{array}{l}\text { Tanggal } \\
\text { Sampel }\end{array}$ & $\begin{array}{c}\text { Masa } \\
\text { Pakai Oli }\end{array}$ & $\begin{array}{c}\text { Viscositas } \\
100^{\circ} \mathrm{C} \\
\text { (cSt) }\end{array}$ & $\begin{array}{c}\text { TBN } \\
\text { (mg.KOH) }\end{array}$ & $\begin{array}{c}\text { TAN } \\
(\mathrm{mg} \cdot \mathrm{KOH} / \mathrm{g})\end{array}$ & $\underset{\text { (ppm) }}{\text { Air }}$ & $\begin{array}{l}\text { Besi } \\
\text { (ppm) }\end{array}$ & $\begin{array}{c}\text { Tembaga } \\
\text { (ppm) }\end{array}$ \\
\hline Oli Baru & 0 & 13.0 & 5 & 0 & 0 & 0 & 0 \\
\hline 10-Des-15 & 1484 & 14.8 & 4.6 & 2.69 & 0 & 1 & 0 \\
\hline 11-Jan-16 & 885 & 14.1 & 2.09 & 1.95 & 0 & 0 & 0 \\
\hline 20-Jan-16 & 910 & 14.2 & 2.5 & 2.30 & 0 & 1 & 0 \\
\hline 28-Mar-16 & 143 & 13.3 & 5.2 & 2.30 & 0 & 1 & 0 \\
\hline
\end{tabular}

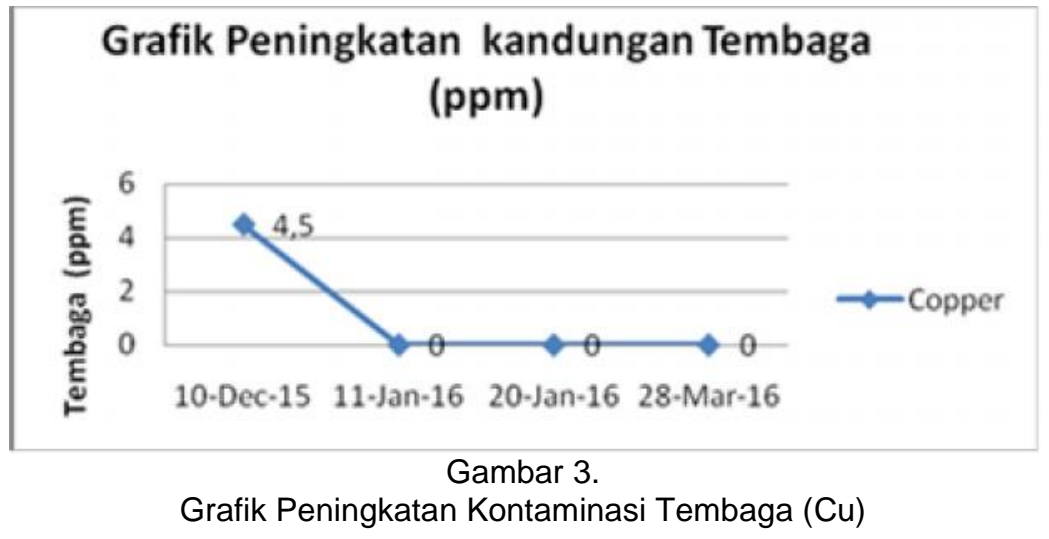


Perbaikan manufaktur Pendingin Udara mesin Pembangkit JGS 420 untuk Mencegah Kontaminasi (Amin Suhadi, Tomi Abdillah)

Grafik padaGambar 3 menunjukkan bahwa setelah dilakukan pergantian material pendingin udara (charge air cooler) dari tembaga menjadi baja tahan karat pelumas tidak lagi mengalami kontaminasi partikel padat tembaga (Cu). Nilai partikel tembaga menunjukkan nol. Hal ini menunjukkan bahwa sumber kontaminasi partikel tembaga yang terdapat didalam pelumas bersumber dari material sirip pendingin udara (charge air cooler) yang mengalami korosi.

\section{Perhitungan Perpindahan Panas (Heat Transfer)}

Perhitungan dan Efektivitas Penukar Kalor Fin Tembaga

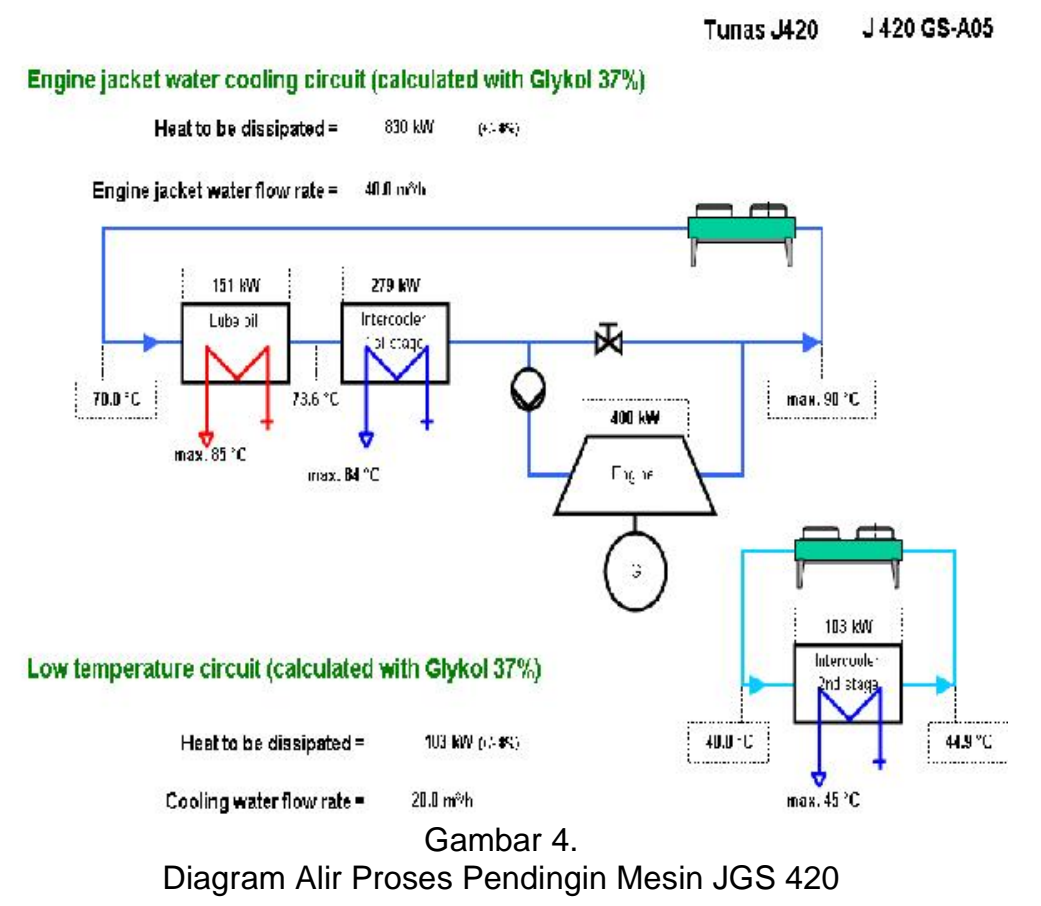

Pada tahap pertama udara akan bertemu dengan satu buah heat exchanger dengan konfigurasi plate fin dan memiliki fluida servis chilled water. Kedua buah heat exchanger tersebut dirangkai seri dalam sebuah tangki bertekanan $^{2,7,8)}$.

\section{Pengujian dengan Simulasi Ansys Heat Exchanger Fin Tembaga dan Stainlees Steel}

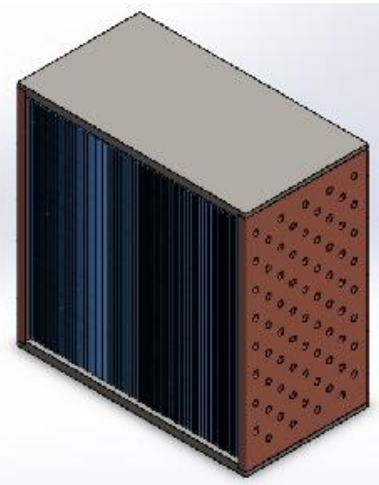

Gambar5.

Model 3D Charge Air Cooler dengan Solidworks
Setelah model Charge Air Cooler (CAC) yang digambar menggunakan perangkat lunak Solidworks, model pada gambar 5 . tersebut di import ke perangkat lunak Ansys.

\section{Simulasi Program Ansys}

Berdasarkan data fisik heat exchanger, perhitungan perpindahan panas fin charge aircooler dan laju aliran massa air didapat data untuk membuat simulasi program Ansys.

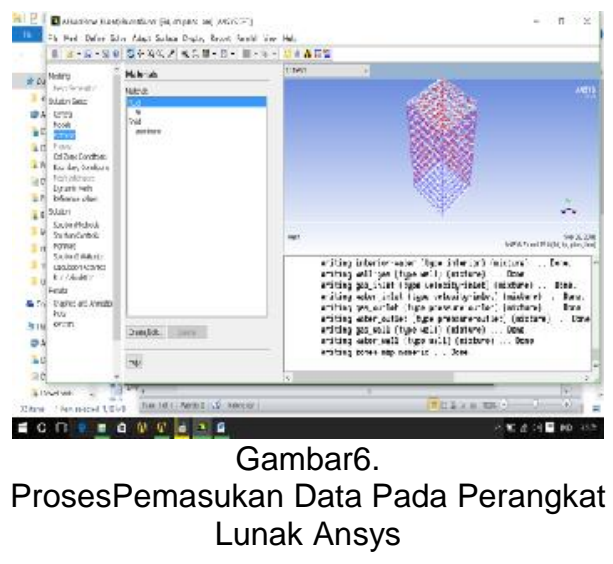


Pada proses ini data-data yang diketahui dari hasil penelitian dan data perhitungan dimasukkan kedalam perangkat lunak Ansys.

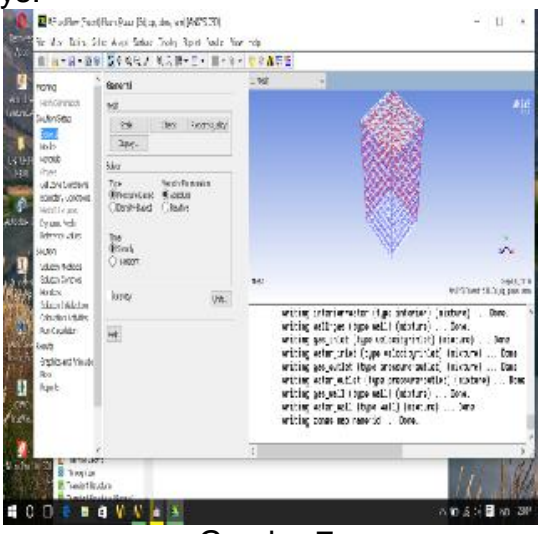

Gambar7.

Proses Pemasukan Data

Pada gambar 7 proses pemasukan data material charge air cooler (CAC) baik tembaga (copper) maupun baja tahan karat (stainlees Steel) pada perangkat lunak Ansys. Dimana properties dari material diambil darireferensi material yang ada di perangkat lunak Ansys ${ }^{4,9,10)}$.

\section{Hasil Simulasi Ansys sirip (fin) Material Tembaga}

Pada Gambar 8, terlihat hasil simulasi menggunakan tembaga, temperatur tembaga mengalami kondisi yang stabil, dimana suhu tembaga mencapai $300^{\circ} \mathrm{K}$ $\left(26.85^{\circ} \mathrm{C}\right)$. Namun dari sisi lain terjadi korosi ketika terjadi perubahan temperatur pada tembaga yang berasal dari udara panas sebesar $150^{\circ} \mathrm{C}$ yang bertemu air dengan suhu $25^{\circ} \mathrm{C}$.

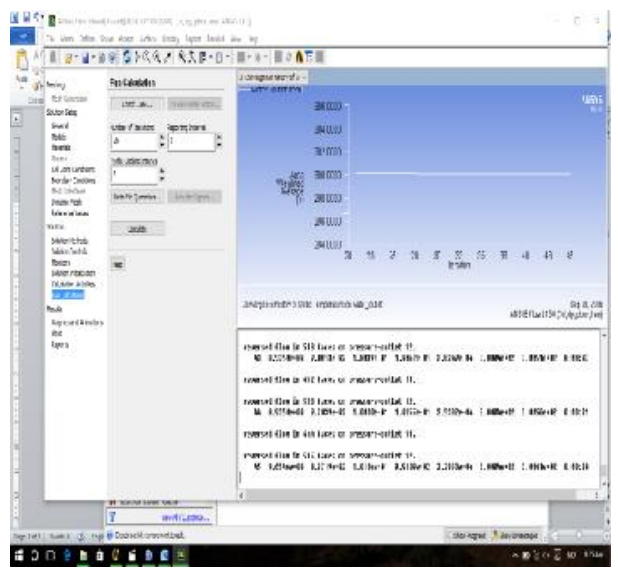

Gambar8

Grafik Temperatur Pada Sirip (Fin)Charge Air CoolerBermaterial Tembaga
Begitu juga dengan kontur temperatur pada sirip (fin)pendingin udara (charge air cooler) bermaterial tembaga berada pada temperatur sekitar $300^{\circ} \mathrm{K}\left(26.5^{\circ} \mathrm{C}\right)$ hampir disemua sirip (fin) pendingin udara (charge air cooler) dengan nilai maksimal sebesar $395^{\circ} \mathrm{K}\left(121.85^{\circ} \mathrm{C}\right)$ seperti yang terlihat pada Gambar 9.

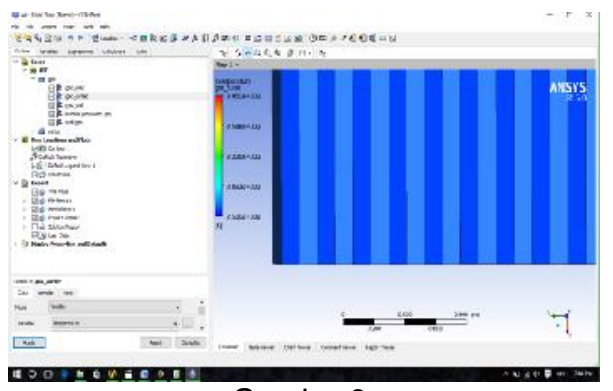

Gambar9.

Kontur Temperatur Pada Fin (Sirip)

Pendingin Udara (Charge Air Cooler) Bermaterial Tembaga

\section{Hasil Ansys Sirip (fin) Material Baja Tahan Karat (Stainlees steel)}

Pada material baja tahan karat (Stainlees steel) terjadi kenaikan temperatur mencapai $301^{\circ} \mathrm{K}\left(27.85^{\circ} \mathrm{C}\right)$ pada iterasi ke-2 namun mulai mengalami keadaan stabil seperti ang terlihat pada Gambar 10. Dari sisi temperatur, material baja tahan karat (Stainlees steel) mengalami kenaikan suhu, namun tidak mengalami signifikan. Disisi lain material sirip (fin) yang berbahan baja tahan karat (Stainlees Steel) tidak mengalami korosi $^{11,12)}$.

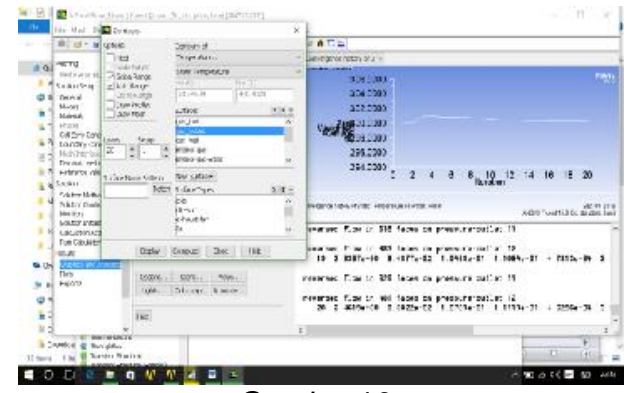

Gambar10.

Grafik Temperatur Pada Siri (fin) pendingin udara (charge air cooler) Bermaterial Baja Tahan Karat (Stainlees steel) 


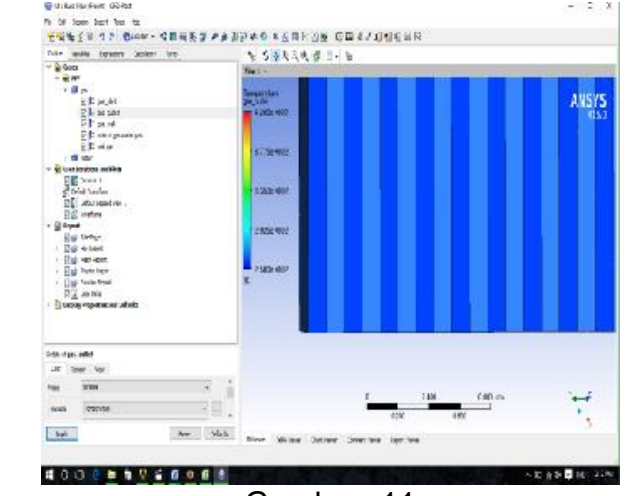

Gambar 11

Kontur Temperatur Pada Sirip ( fin) pendingin udara (charge air cooler bermaterial Baja Tahan Karat (Stainlees steel)

Pada material baja tahan karat (stainlees steel) terjadi peningkatan suhu pada bagian sirip (fin), namun masih bisa dipakai untuk menggantikan material tembaga ${ }^{13,14,15)}$. Diketahui bahwa terjadi nilai temperatur maksimal sebesar $420^{\circ} \mathrm{K}\left(146.85^{\circ} \mathrm{C}\right)$ seperti yang terlihat pada Gambar 11.

\section{Gambar Desain Pendingin Udara (Charge Air Cooler) Mesin Gas JGS 420 Dengan Solid Work}

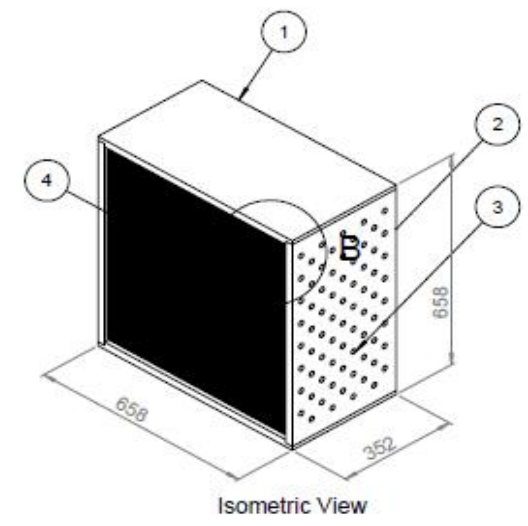

Gambar 12

Gambar Komponen Utama Charge AirCooler (CAC)

Keterangan Gambar

1. Top bottom plate

2. Side plate

3. Pipa

4. Sirip (fin)

\section{SIMPULAN}

Dari hasil penelitian perbaikan proses manufaktur dengan pemanfaatan material baja tahan karat (stainless steel) sebagai pendingin udara (charge air cooler) pada mesin gas JGS 420 maka diperoleh simpulan sebagai berikut.

Pemanfaatan material baja tahan karat (Stainless steel) sebagai pengganti material tembaga sebagai sirip pendingin udara (charge air cooler) dapat mengurangi kontaminasi dan mewujudkan efisiensi umur (life time) pelumas. Berdasarkan pengujian used oil analysis (UOA) Signum Exxon mobil di Melbourne Australia tanggal 22 Desember 2015, tanggal 19 January 2016, tanggal 27 January 2016 dan tanggal 5 April 2016 hasilnya menunjukkan tidak terdapat kandungan tembaga (cu).

Selanjutnya, kontaminasi partikel copper $(\mathrm{Cu})$ didalam pelumas mesin gas JGS 420 melebihi ambang batas yaitu 204 (ppm). Sumber kontaminasi berasal dari sirip-sirip pendingin udara (charge air cooler). Sebelum udara masuk ke dalam ruang bakar untuk proses pembakaran bahan bakar gas maka udara didinginkan melalui pendingin udara (charge air cooler) dengan media air yang terdapat didalam pipa-pipa pendingin udara. Pendingin udara (charge air cooler) memiliki 2 tingkatan (double stage). Tingkatan pertama temperatur air masuk $70^{\circ} \mathrm{C}$ dan tingkatan kedua temperatur air $47^{\circ} \mathrm{C}$

Selain itu, proses pendinginan udara dari temperatur $150{ }^{0} \mathrm{C}$ menjadi $50{ }^{\circ} \mathrm{C}$ mengakibatkan proses kondensasi pada permukaan fin charge air cooler sehingga lambat laun menjadi korosif ${ }^{16,17}$.

Kemudian, desain gambar charge air cooler menggunakan Solid works 2014 dengan dimensi charge air cooler mengikuti dimensi pembuat mesin (engine maker) yaitu : P x L x T = $658 \mathrm{~mm} \times 658 \mathrm{~mm} \times 352 \mathrm{~mm}$. Diameter luar pipa didalam pendingin udara (charge Air Cooler) : 0,625 x 25,4 mm, Diameter luar pipa didalam pendingin udara (charge Air Cooler) : 0,527 mm.

Dari program simulasi Ansys diperoleh bahwa temperatur keluar (out put) pendingin udara (charge air cooler) yang terbuat dari material baja tahan karat (stainless steel) tidak berbeda jauh dengan material tembaga. Temperatur udara setelah melewati pendingin udara dengan material tembaga adalah $50{ }^{\circ} \mathrm{C}$, sedangkan temperatur setelah melewati pendingin udara dengan material baja tahan karat adalah 60 ${ }^{0} \mathrm{C}$.

\section{UCAPAN TERIMA KASIH}

Penulis mengucapkan terima kasih kepada Ka B2TKS danketua program Pasca Sarjana Magister Teknik Universitas Pancasila atas segala bantuan dan 
dorongan sampai terlaksananya penelitian ini.

\section{DAFTAR PUSTAKA}

1. Jhon R.Heywood, Internal combustion Engine fundamentals, Mc Graw Hill, 1988.

2. Wiranto Arismunandar, Penggerak Motor Bakar Torak, edisi ke empat, Internal Combustion Engine penerbit ITB, 1988.

3. GE Jenbacher,JGS 420 Manual Book, 2007.

4. Ramesh K.Shah dan Dusan P.Sekulik, Fundamentals of Heat Exchanger Design, John wiley and sons inc, New Jersey, 2003.

5. Philip A.Schweitzer, P.E, Metallic Materials Physical, Mechanical And Corrosion Properties, Marcell Dekker inc, 2003.

6. Amimul Ahsan, Evaporation, Condensation And Heat Transfer, Intech Croatia, 2011

7. Benjamin Valdez Salas, Jurnal Copper Corrossion by Atmospheric Pollutants in The Electrocic Industry, Engineering Institute, Autunomous University of Baja California, August 232013.

8. Material Science Volume 1 of 2, U.S Department of Energy, Washington DC, 1993
9. CRC Handbook of Lubrication, Theory And Practice of Tribology, Volume II, General Electrict Company, New york 1983.

10. Charles Fayette Taylor, The Internal Combustion Engine in Theory and Practice, Volume 1 2nd edition, The MIT press Cambridge Massachussetts.

11. H.N Gupta, Fundamentals of Internal Combustion Engine, second edition, $\mathrm{PHI}$ learning PVT.Ltd, 2012.

12. Gamesan V, , Tata Mc Graw hill, 2003.

13. Pierre R.Roberge, Handbook of Corrosion Engineering, Mc Graw Hill, 1999

14. Robert Scott, Lloyd lougner, Practical Handbook Machinery Lubrication, Noria corporation, 2012.

15. Ashby, M.F, Materials Selection in Mechanical Design, Butterworth, Oxford, 2006.

16. Friterm A.S, Technical Document, Research \& Development Department, Charge Air Cooler (CAC), 2006

17. Adrian Bejan dan Allan D Kraus, Heat Transfer Handbook, Jhon Willey \& Sons Inc, 2003. 